\title{
Quality Assurance in Moving and Handling Education: Myth or Legend
}

\author{
Gwarancja jakości w edukacji dotyczącej podnoszenia i przemieszczania pacjentów: mit czy legenda
}

\section{Kevin Hares ${ }^{1}$, Stephen Wanless ${ }^{1}$}

Institute for Posture, Movement and Handling, Birmingham City University

\section{CORRESPONDING AUTHOR: \\ Kevin Hares \\ Birmingham City University, Faculty of Health, Education and Life Sciences \\ Seacole Building, City South Campus \\ Westbourne Road, Edgbaston, Birmingham. B15 3TN. \\ e-mail: Kevin.hares@bcu.ac.uk \\ tel: 01213317994}

\begin{abstract}
STRESZCZENIE GWARANCJA JAKOŚCI W EDUKACJI DOTYCZACEJ PODNOSZENIA I PRZEMIESZCZANIA PACJENTÓW: MIT CZY LEGENDA

Wprowadzenie. Brak gwarancji jakości w zakresie edukacji dotyczącej podnoszenia i przemieszczania pacjentów prowadzi do niezgodności w szkoleniu i ćwiczeniach.

Cel pracy. Artykuł omawia implikacje dla ćwiczeń oraz potrzebę bardziej rzetelnych ram regulacyjnych i standardów, które należy wprowadzić w obrębie Unii Europejskiej.
\end{abstract}

Słowa kluczowe: gwarancja jakości, edukacja podnoszenia, standard w praktyce

\begin{abstract}
QUALIY ASSURANCE IN MOVING AND HANDLING EDUCATION: MYTH OR LEGEND

Introduction. The lack of quality assurance within moving and handling education leads to an inconsistency in training and practice. Aim. This article discusses the implications for practice and the need for a more robust regulatory framework and standards to be adopted within the European Union.
\end{abstract}

Key words: $\quad$ quality assurance, handling education, standard in practice

\section{INTRODUCTION}

Moving and handling in the clinical setting is a skill that needs the theory linked to practice and an individual's practical experiences. It was thought that by introducing the Manual Handling Operations Regulations [1] and the recommendation of making moving and handling training mandatory this would reduce the number and severity of incidents. Staff within the healthcare and social care professions exhibit high rates of musculoskeletal pain that has been connected to patient handling [2]. These remain a key reason for sickness and absence across all areas of the National Health Service [3,4]. Hazardous and outdated patient handling techniques continue to be used by healthcare workers augmenting the chance of injury to themselves and also their patients $[5,6]$. Poor moving and handling positioning and technique, and the lack of use of equipment where available, will also impact on a patient's safety and experiences $[7,8,9]$.

Organisations have a legal duty to ensure healthcare workers are adequately prepared for their clinical duties and the moving and handling activities that they may encounter whilst in a clinical area [1]. The literature identifies problems with this provision $[10,11]$ and the failing of health and social care organisations in taking advantage of the opportunities and benefits of inter-professional learning when delivering moving and handling education. A number of organisations publish standards and guidelines to inform health and social care organisations and trainers of their roles and duties but they are only able to provide guidance, not make regulatory statements.

Standards in Manual Handling [12] set out the expectations for a training programme based on the experience of the individual attending. The content was based upon the methods and approaches in the Guide to the Handling of People 5th edition [13] (Smith 2005) and the requirements listed in Manual Handling Operations Regulations 1992 guidance issued by the Health and Safety Executive (HSE) [1], and many trainers in healthcare Trusts and organisations claim to base their training programmes upon these. Despite this there is no single professional body that accredits or regulates moving and handling training and practice. 
The Quality Assurance Agency for Higher Education (QAA) is an organisation that has published the UK Quality Code for Higher Education [14] which seeks to set and maintain academic standards by creating a series of frameworks against which teaching and learning can be benchmarked. Although providing guidance on how to work with other organisations and assure quality of teaching for levels of qualification they do not contain subject specific indicators, such as moving and handling, which need to be determined from other sources of evidence.

\section{Quality assurance}

The Quality Assurance Agency for Higher Education defines quality as: "... a way of describing how well the learning opportunities available to students help them to achieve their award" [15],

Evidence disputes that quality has anything to do with describing, and agreement is difficult to find elsewhere in the literature $[16,17]$. The above definition is not included in the Revised UK Quality Code for Higher Education [18]. Difficulties in measuring quality, and gaining assurance, are of particular relevance when teaching safer moving and handling practices to healthcare workers as a similar lack of cohesiveness exists regarding how to teach this subject for maximum clinical application.

Studies exploring the continued prevalence of musculoskeletal injuries in healthcare staff and students demonstrates the need for effective training in moving and handling [19,20], and this situation persists despite the wide availability of training provision and the supply of equipment to assist with these tasks $[4,21,22]$. Wanless [23] states that these injuries have serious repercussions on the individuals' lives, both occupationally as well as personally, and is a significant contributor to the shortage of healthcare workers. This impact would include the learning experience of employees and students during their mandatory moving and handling training.

Although a general consensus has been reached that moving and handling practice should be evidenced-based as far as possible [24], no universal agreement on a unified approach has been adopted in the UK despite a number of guidance publications being issued [25-28]. Several studies have highlighted that training in moving and handling practice is not being effectively transferred into daily clinical application $[5,23,29,30]$, and anecdotal reports from healthcare workers and students attending training confirm that this remains the case. The QAA [31] states that learning occurs when new behaviours, skills or values are acquired. If the training provided within the healthcare establishments and places of work is not transferring into application it is probable that employees will continue to use inappropriate methods and newly qualified staff and students will adopt poor practice.

The QAA framework requires awarding organisations to undertake due diligence to ensure that partner organisations provide a safe working environment for students on placement [32]. In order to do this, organisations need to ensure that employees and students are aware of their responsibilities to patients whilst in the clinical setting [31] and benchmark moving and handling learning both for themselves and the partner organisation against published best practice guidance for content and consistency.

\section{Standards in practice}

Within the sphere of moving and handling training, the most widely recognised publications that apply to standards of practice and teaching for healthcare professions are published by National Back Exchange (NBE) [12] and BackCare $[13,33]$. These three documents purport to set standards for practice and define the current best practice methods based upon the current available evidence. The effect of the guidance from NBE is that many providers simply teach the techniques in the editions of the Guide to the Handling of People [13,33]. This leads to superficial learning of techniques and staff are then unable to adapt when faced with novel situations. Hignett's [34] study found that technique-driven training was ineffective resulting in little change in the handling culture of staff. Hamilton [35] observes that unused skills decline faster than knowledge which would explain why staff "revert to type" [36] when faced with new or infrequent handling situations. It also accounts for employees delivering poor practice in the clinical area which coerces new employees and students into conforming to local norms [23,37-40] and perpetuates old methods of practice.

There are organisations who provide their own sets of guidelines but to date these have not been coordinated in any format to provide one national set of standards. Skills for care and development are an association of six organisations which form the Sector Skills Council for social care, children and young people's services. Skills for care is a government funded independent registered charity which works with adult social care employers to set the standard and qualifications to provide social care staff with the skills and the knowledge to deliver a high quality of care to their service users. A range of several core moving and handling units have been developed for these qualifications directed at staff who work in these areas. The units give a clear direction as to the number of guided learning hours that each learner is expected to complete and a significant amount of time is dedicated to moving and handling practice, although this does not meet the published standards of National Back Exchange or the requirements of the guidance on the legislation [41].

The National Health Service Litigation Authority is an organisation whose primary function is to contribute to the reduction in the number of preventable incidents [42] It achieved this through a risk assessment programme that included setting standards for moving and handling against which a healthcare organisation can be audited [43].

\section{Compliance}

With this lack of clarity and consistency, it is no wonder that in practice settings where time is scarce there is confusion where nurses and healthcare professionals try to work together using differing training approaches and standards [44]. This leaves the healthcare profession with a range of different options which are not designed for integrated and collaborative work and clearly presents 
a potential quality assurance issue as it does not conform to what many consider to be the recognised standards for regular training. Although these are standards held in wide regard by moving and handling trainers they are actually followed by few organisations in their entirety.

The review conducted by Hignett [5] revealed that few organisations implemented the guidance of the time, and with increased time and financial pressure many healthcare providers have sought to further reduce the training time and frequency that their staff get for manual handling. This study highlighted that few institutions met the requirement for the standards with only an average of forty seven percent who demonstrated any compliance. The institutions with the best compliance showed lower levels of postural risk and staff had a better understanding of problem solving ability when they were patient handling. Hignett's [5] study found issues between what is regarded as accepted best practice and what is actually research evidenced.

To enhance the quality of moving and handling education and training it is proposed that partner organisations where students are placed for the experiential components of their programmes adopt a principles-based form of training. A programme based upon both published evidence and research would prove its efficacy [23] and ensure a robust strategy for meeting quality requirements whilst complying with QAA indicators $[14,18,31,32]$ as well as the Nursing and Midwifery Council (NMC) requirements [45]. Partnerships between universities and organisations could meet the CPD requirements of the moving and handling training teams and improve the consistency and quality of educational approach. The advantages to the partner organisations would include the reduced time that training staff are released from the workplace and consistency across the regional healthcare providers for this aspect of education and practice. Training teams also would be confident of the knowledge that they shared and be able to refer back to the evidence to support the processes used by their staff.

\section{SUMMARY}

By adopting a standardised approach to moving and handling education, employees will be able to apply their learning to situations they haven't previously encountered. This was demonstrated in Wanless' [23] study on nursing students who exhibited better retention of their knowledge and applied behaviours as well as correlating benefits in terms of "patient" communication. The study also proved the efficacy of its programme by reducing reported student moving and handling injury rates by $92 \%$ since implementing this programme [23]. The potential weaknesses in this approach relate to human nature and finance. If local training teams are not prepared change the way that they train, or their employers will not invest in the change and education of their teams and staff, then the opportunity to increase consistency and quality assurance will be lost to both parties.

As there is no agreed standard or approach to moving and handling education, there is also a need for regulatory enforcement. Unfortunately, not only does agreement not currently exist regarding a standard/strategy, but the political climate is ensuring that regulatory agencies take a "light touch" unless there is a serious untoward incident. If this barrier can be negotiated around, then there is a chance to improve education and musculoskeletal injury for all staff.

\section{REFERENCES}

1. Health and Safety Executive. Manual Handling Operations Regulations 1992 (as amended). Guidance on the regulations L23 (3rd edition). Suffolk: HSE Books; 2004.

2. Smedley J, Williams S, D'Arcy P, et al. Back pain management: 0 ccupational health practice in the NHS in England. A national clinical audit - round 2. London: Royal College of Physicians; 2012.

3. Department of Health. Back in work back pack - everything you need to know about the National Back in Work campaign. London: Crown Copyright; 2002.

4. Health \& Safety Executive. Health and Safety at Work, Summary statistics for Great Britain; 2017. http://www.hse.gov.uk/statistics/overall/hssh1617.pdf accessed 27/02/18.

5. Hignett, S. Measuring the effectiveness of competency-based education and training programmes in changing manual handling behaviour of healthcare staff. Research report 315. Norwich: HMS0; 2005.

6. Elnitsky CA, Lind JD, Rugs D. Implications for Patient Safety in the use of Safe Patient Handling Equipment. International Journal of Nursing Studies. 2014; 51(12): 16241633.

7. Kjellberg K, Lagerstrom M, Hagberg M. Patient safety and comfort during transfers in relation to nurses' work technique. Journal of Advanced Nursing. 2004; 47(3): 251-259.

8. Randall S. Looking after your health: Avoiding back injury. Practising Midwife. 2014; 17(11): 10-14.

9. Wanless S, Wanless SG. Hoisting a patient: Principles for safer practice. International Journal of Therapy and Rehabilitation. 2015; 22(8): 390-395.

10. Kneafsey R, Baker C, Robinson J. Ten years on from the 1992 'Manual handling operations regulations': a perspective from higher education in the UK. Nurse Education in Practice. 2003; 3: 121-122.

11. Anderson MP, Carlisle S, Thomson C, et al. Safe moving and handling of patients: an interprofessional approach. Nursing Standard. 2014; 28(46): 37- 41.

12. Ruszala S, Hall J, Alexander P. Standards in Manual Handling 3rd edition. Towcester: National Back Exchange; 2010.

13. Smith J. The Guide to the Handling of People (5th edition). Teddington: BackCare; 2004.

14. Quality Assurance Agency for Higher Education (2018). http://www.qaa.ac.uk/ assuring-standards-and-quality/the-quality-code accessed 10/05/18.

15. von Prondzynski F. (2018) What is quality in higher education? https:// universitydiary.wordpress.com/2008/10/09/what-is-quality/ accessed 14/05/18.

16. Schindler L, Puls-Elvidge S, Welzant H, Crawford L (2015). Definitions of Quality in Higher Education: A Synthesis of the Literature. https://www.researchgate.net/ publication/284217681_Definitions_of_Quality_in_Higher_Education_A_ Synthesis_of_the_Literature accessed 05/05/18.

17. Elassy N. "The concepts of quality, quality assurance and quality enhancement", Quality Assurance in Education. 2015; 23(3): 250-261 https://doi.org/10.1108/QAE11-2012-0046 accessed 05/05/18.

18. Quality Assurance Agency for Higher Education (2018). Revised UK Quality Code for Higher Education. UK Standing Committee for Quality Assessment: https://ukscqa. org.uk/what-we-do/consultation-on-the-uk-quality/ accessed 05/05/18.

19. Hodder JN, Mackinnon SN, Ralhan A. Effects of training and experience on patient transfer biomechanics. International Journal of Industrial Ergonomics. 2010; 40(3): 282-288.

20. Videman T, 0jajärvi A, Riihimäki H, Troup JDG. Low Back Pain Among Nurses. A Follow-up Beginning at Entry to the Nursing School. Spine. 2005; 30(20): 23342341.

21. James A. in Ruszala S, Hall J, Alexander P. Standards in Manual Handling 3rd edition. Towcester: National Back Exchange, 2010.

22. Davis KG, Kotowski SE. Prevalence of Musculoskeletal Disorders for Nurses in Hospitals, Long-Term Care Facilities, and Home Health Care: A Comprehensive Review. Human Factors 2015; 57(5): 754-792.

23. Wanless SG. Improving the effectiveness of motor skills learning in moving and handling training for the healthcare environment. Ph.D. Thesis, Birmingham City University; 2016. 
24. Crumpton E, Johnson C. "Introduction to the practical chapters". In Smith, J (ed.) The Guide to the Handling of People 5th edition, 117-121. BackCare: Teddington; 2005.

25. Health \& Safety Executive (2003). The Principles of good manual handling: achieving a consensus RR097 Research Report, http://www.hse.gov.uk/research/rrpdf/rr097. pdf accessed 02/05/18.

26. All Wales Trust Manual Handling Advisors Group (2003). All Wales NHS Manual Handling Training Passport and Information Scheme. Wales: All Wales

27. All Wales Trust Manual Handling Advisors Group v2 (2010). All Wales NHS Manual Handling Training Passport and Information Scheme. Wales: All Wales

28. Scottish Government (2014). The Scottish Manual Handling Passport Scheme. http://www.hse.gov.uk/scotland/pdf/manual-passport.pdf accessed 02/05/18

29. Fanello S, Frampas-Chotard V, Roquelaure Y, et al. Evaluation of an Educational low Back Pain Prevention Program for Hospital Employees. Revue du Rheumatisme English edition. 1999; 66 (12): 711-716.

30. Crumpton E, Bannister C, Maw J. Survey to Investigate NHS Trusts' Compliance with the RCN Safer Patient Handling Policy 1996. Unpublished version of report; 2002.

31. Quality Assurance Agency for Higher Education (2018). Part B: Assuring and Enhancing Academic Quality. Chapter B3: Learning and Teaching. http://www. qaa.ac.uk/assuring-standards-and-quality/the-quality-code/quality-code-part-b accessed 05/05/18

32. Quality Assurance Agency for Higher Education (2018). Part B: Assuring and Enhancing Academic Quality. Chapter B10: Managing Higher Education Provision with 0thers. http://www.qaa.ac.uk/assuring-standards-and-quality/the-qualitycode/quality-code-part-b accessed 05/05/18

33. Smith J. (editor). The Guide to the Handling of People (6th edition). Teddington: BackCare; 2011

34. Hignett $S$. Intervention strategies to reduce musculoskeletal injuries associated with handling patients: a systematic review. Occupational and Environmental Medicine. 2003; 60: E6.
35. Hamilton R. Nurses' knowledge and skill retention following cardiopulmonary resuscitation training: a review of the literature. Journal of Advanced Nursing. 2005: 512(3): 288-297.

36. Petty G. Chapter 31: Learning from experience. Teaching Today a practical course (2nd edition). Cheltenham: Nelson Thornes; 1998, s. 287-295.

37. Kneafsey R. The effect of occupational socialisation on nurses' patient handling practice. Journal of Clinical Nursing. 2000; 9(4): 585-593.

38. Travis M. Handling training. Nursing Standard. 2000; 14(23): 53.

39. Swain J, Pufhal E, Williamson GR. Do they practice what we teach? A survey of manual handling practice amongst student nurses. Journal of Clinical Nursing 1. 2003: 2(2): 297-306.

40. Cornish J, Jones A. Factors affecting compliance with moving and handling policy: Student nurses' views and experiences. Nurse Education in Practice. 2010; 10(2): 96-100.

41. Health and Safety Executive. Manual Handling Operations Regulations 1992 (as amended). Guidance on the regulations L23 (4th edition). Suffolk: HSE Books; 2016.

42. McGurk, G. NHS Litigation Authority. Nursing Standard. 2014; 28(34): 32.

43. NHSLA Risk Management standards 2012-13. London; NHSLA: 2012

44. Kneafsey R, Clifford C, Greenfield S. Perceptions of hospital manual handling policy and impact on nursing team involvement in promoting patients' mobility. Journal of Clinical Nursing. 2015; 24, 1: 289-299.

45. Nursing and Midwifery Council (2010). Standards for pre-registration nursing education.https://www.nmc.org.uk/globalassets/sitedocuments/standards/nmcstandards-for-pre-registration-nursing-education.pdf accessed 28/02/18.

Manuscript received: 13.07.2018

Manuscript accepted: 23.08.2018 